\title{
Delivering sustainable buildings and communities: eclipsing social concerns through private sector-led urban regeneration and development
}

Increasingly, government urban growth strategies support streamlined planning and development processes that soften conditions for private sector developers in the construction and development of "sustainable buildings" and "sustainable communities". Encouraged by a popular embracing of urban intensification as an approach to urban development, these strategies often strengthen the role of private sector intermediaries and consultants in local policy networks (Hackworth and Smith 2001, Adair et al. 2003, Steinacker 2003, Davidson and Lees 2005). Public sector reliance on private sector finance, skills and resources in the delivery of a sustainable built environment has been documented as problematic due to the proliferation of less than optimal sustainable performances, rising land values and expensive housing developments in many new and regenerated areas of our towns and cities (Adair et al. 2003, Lees 2003, Bromley et al. 2005, Krueger and Agyeman 2005, Raco 2005, 2007, Boddy 2007, Gibbs and Krueger 2007, Keil 2007). Generic design, inequitable access to sustainable spaces, unchecked costs, market premiums and un(der)regulated design quality compliance are amongst a host of concerns, complicating the aspirational intentions of policymakers dependent on the private delivery of the "public good" of sustainability. The onset of a global credit crisis puts the reliance on the risk-averse private development sector to deliver sustainable built environments into poignant, and yet evocatively transformative, relief.

Surprisingly, however, there is little critical discussion within the existing literature on the direct linkages between private sector involvement in policy networks and processes and the optimisation of the physical and social environments that result from the planning and construction of so-called sustainable buildings and communities. A growing literature expands upon the relationships and tensions between neo-liberal governance and urban sustainability, but case studies specifically addressing "on the ground" associations between public sector policy and private sector delivery for the production of sustainable buildings and communities are few. Hence, the critical space for this special issue, which emerges out of two very successful sessions of the 2008 Association for American Geographers (AAG) Annual Meeting in Boston, MA, USA. The idea for the sessions originated from our mutual interest and involvement in research at the knowledgepolicy-practice interface of urban development and regeneration in Canada and the UK. Our early discussions quickly turned to the problems and opportunities associated with the noted convergence of public and private sectors in the implementation of sustainable urban regeneration and development schemes in cities, and in particular the underscrutinised role of private sector development interests in the formulation and delivery of growth-related public policy agendas. The conference sessions addressed neo-liberal governance restructuring and influence but specifically focused on a discussion of localised 
instigators of private sector-led development activities and the impacts of these practices on the ground, in real homes and communities.

The papers brought together in this special issue complement and challenge each other some reflecting on the triple-bottom line imperative of sustainability in urban planning and development-oriented policy processes, and others revisiting the debates on ecological modernisation and benchmarking progress (in support of evidence-based policy) in the physical construction and assessment of individual "green" buildings and the regeneration of whole urban areas (cf. Moore and Rydin 2008). The contributors to the issue represent a range of thematic fields including human geography, planning and urban development, architecture, environmental studies, urban political ecology and environmental policy. An integral aspect of the papers is both their multi-disciplinary representation and their empirical and theoretical inter-disciplinarity. The papers point to an emerging international agenda for research on the associations between urban sustainability policy, urban redevelopment and urban planning that surpasses disciplinary boundaries and allows for an interdisciplinary focus on the problem of private sector delivery of sustainability policy. Our invited critical discussants, James Evans, Phil Jones and Rob Krueger, echo the significance of this research in their timely proposition for an "organic" reconstitution of regeneration policy and practice that transcends the non-inclusive boundaries of dominant urban development models.

\section{Eclipsing the social in the sustainability building challenge?}

A concern for conference session convenors is that somewhere between accepting an abstract and delivering the paper, individual participants drift away from the common thematic remit of the session. To some extent we could say this was the case for our AAG sessions - but the upshot of this situation was that something more revealing and constructive emerged. Rather than merely focusing on the increasing role of private sector interests in sustainable urban development and regeneration projects and policy agendas, the majority of the papers elicited a warning call for policy and decision makers. Do not neglect nor presume the social in "sustainable" schemes, programmes and policies. Such a refrain provided a common thread for intervention into the problematic of the localised delivery of sustainability policy and emerges as the central framework for the presentation of papers in this issue. Each of the core papers uses local case study research to interrogate and dislodge traditional conceptual and applied interpretations of sustainability and demonstrates the need for effective practices that address social disparities and injustices. As the private sector delivery of government sustainability policy becomes the norm for built form redevelopment in cities and market-oriented sustainable housing grows in popularity, concerns about the de-emphasis of social equity and justice in sustainability policy formulation and implementation are also increasingly important. The papers discuss such issues as the connections between multi-scalar government sustainability policy, "on the ground" gentrification practices, the development of market oriented buildings and the use of sustainable design ratings such as Leadership in Energy and Environmental Design (LEED), and the ways in which discourses of sustainability policy connect or collide with existing strategies for built form redevelopment in cities. Collectively, these papers provide evidence furthering scholarly discussion of the need to address social concerns in sustainable urban redevelopment agendas and projects at a variety of scales.

In a discussion of social sustainability agendas enacted at the urban municipal level, Davidson cautions that out of the shadows of neo-liberal individualism a progressive political insistence on "the social" is beginning to permeate metropolitan politics in 
western cities. Sustainability is the normative policy vehicle of choice, enabling all manner of "responsible" political actions which to date have tended to prioritise environmental and economic issues over the social (Littig and Greissler 2005). The social tenet of sustainability is inevitably the messy pillar of the tri-partite model, and its delivery likely to be challenged due to oscillating interpretations and entrenched subjectivities. The bundling of "the social" together with "sustainability" is then an ideological project that engenders highly variable political rationalities and responses in different urban contexts. Davidson effectively argues, with reflection on the cases of Vancouver and Sydney, the need to decouple urban policy emphases placed on the social from those on sustainability in an effort to understand the distinctiveness of the political spheres of debate that each constitutes. In other words, to critically examine what "social" is being "sustained"; how, why, by and for whom? Such dissection of universally conceptualised and applied definitions of social sustainability, Davidson suggests, is a necessary precursor to the effective utilisation of any model of sustainability to foster real political debate. This debate is particularly important for challenges to the hegemony of neo-liberalism in urban policy structures and processes and questioning the un-reflexive adoption and application of sustainability.

Cidell utilises an urban political ecology framework to investigate the hybridity of built environments constructed in-line with the "best practice" performance standard of the LEED programme. She argues that LEED has effectively promoted cities with strong "green" attributes, but, like Davidson, queries the political and ideological construction of sustainability agendas and suggests that such schemes are devoid of, or at best indifferent to, the role of the social and society. Her paper encourages us to despatch with the dualism of human versus "nature" implicit in our use of the term "built environment" and to look at green building programmes and standards, like LEED, as socio-material pathways (cf. Guy and Shove 2000, Guy and Farmer 2001, Moore and Engstrom 2005) demonstrable of discursive progress/regress in urban socio-nature relations.

Whereas the focus on "green buildings" might promote an emphasis on technological capacity-building within the construction industry and "product" performance in the development sector, Redmond and Russell remind us that these products are also people's homes, and together they form real neighbourhoods and communities. Focusing on the regeneration of Irish housing estates, their paper builds upon the theme of the AAG sessions by looking in detail at public-private partnership (PPP) delivery mechanisms in the pursuit of sustainable communities. Crucially, it situates the debate about social sustainability at the urban neighbourhood scale. The paper identifies the multiple subjectivities and meanings inscribed within and through the policy directive to demolish and replace existing estates, publicly deemed as "unsustainable", with a market-driven model for mixed tenure "regenerated" and socially- (or more accurately, economically-) stable communities. Redmond and Russell's review of social housing regeneration processes in Dublin is instructive as much as it is incisive. Their intention is to examine the gap between aspirational policy formulation and implementation in real communities, but in the process they demonstrate the extent to which the consultation-orientated regeneration programmes overlook residents' conceptualisations of their own communities and their subjective meaning of "sustainability". In this particular case, the emphasis is placed on "the social" with a clear mandate for providing "integrated communities" but as Redmond and Russell illustrate, the constitutive attributes of the social components for a sustainable community are unmistakably shallow and constrained.

In another analysis of the implementation of sustainable urban regeneration policy at the urban neighbourhood scale, the paper by Bunce identifies the associative relationships 
between sustainability policy, private sector developer implementation and gentrification processes in the West Don Lands area of Toronto's waterfront. Urban waterfront development has attracted growing academic and government attention over the past 5 years due to a renewal of public and private sector efforts in waterfront regeneration around the world (Schubert 2001, Desfor and Jorgensen 2004, Desfor and Keil 2004, Cowen and Bunce 2006, Bunce and Desfor 2007, International Network of Urban Waterfront Research Conference - Hamburg 2008). Recent research has focused on urban waterfront regeneration as a key driver in support of inter-urban competition (Desfor and Jorgensen 2004), global "place-making", as well as processes of urban built form intensification (Bunce and Young 2004). Bunce's paper looks specifically at how sustainability acts as an umbrella under which policies and strategies promoting waterfront gentrification are enabled through an integrative connection of public planning agendas with market-led private development objectives. Resonating with Cidell's analysis of the impact of the LEED standard on the "types" of cities promoted, Bunce turns a critical lens to the specificity of Toronto's waterfront for cues to understand how best practice rating systems, like LEED and other policy-led incentives and programmes, fuel the political and social acceptance of gentrification. The argument being that urban waterfront gentrification in Toronto has enjoyed relative immunity from critical attention because of its alignment with the (economically and politically, even if not socially-equitably) sanctified process of "developing sustainability". Bunce cautions, however, that "sustainability adds a new layer of complexity to the associations between government and private developers in planning, land development and the provision of housing" (p. 659, this issue), which points to the inclusion of sustainability in a third wave gentrification process (cf. Hackworth and Smith 2001, Hackworth 2002). The latter is characterised as a gentrification process supported by the formation of PPPs and alliances in support of urban development objectives, and government policies that encourage the private sector, market-oriented development of urban real estate. Bunce suggests that a third wave gentrification process is evident in the West Don Lands as a result of a multi-scalar governmental effort to ameliorate planning conditions placed upon private sector land investors for the purpose of reducing the perceived risks associated with building and developing a sustainable community.

Urban regeneration and redevelopment projects invariably create changes for urban social relations, be it impacts on existing residents, adjacent residents or the potentiality of future residents in an area. Bunce's review of the Toronto Waterfront Revitalization Corporation's practices in the gentrifying space of the West Don Lands suggests that "sustainable communities" may become the domain of urban elites, marginalising (or ignoring) social justice and equity concerns in the process. Likewise, Redmond and Russell draw attention to the lack of local accountability in the definition and implementation of the preferred models for "integrated" community development in Dublin's market-based estate regeneration programme. Adding to the gentrification-sustainability debate, Dale and Newman's case studies of brownfield, infill development processes, and sustainable actions in Vancouver, Victoria's Dockside Green and Toronto's Kensington Market neighbourhoods highlight the critical question underpinning the thrust of concern for an eclipse of the social in sustainability agendas, policies and schemes expressed in all five core papers: are we enabling sustainable development for some? At what cost to our urban futures?

Such questions provoke a new mode of critical inquiry into the continued growth of support for sustainable urban regeneration agendas by governments around the world, and suggest that it is through answering such questions that richer and more socially just concepts of sustainability can be reached. Certainly, the papers in this special issue point to a future re-imagining of sustainability concepts in favour of social equity and social 
justice through a variety of practices. This may involve, as these five papers suggest, considerations for lessening the public reliance on private sector delivery of sustainable buildings and the re-establishment of the public provision of affordable housing in cities, the involvement and agency of socially marginalised citizens in the creation of urban sustainability agendas and the formulation of urban sustainability policies with more critically reflexive and politically attuned understandings of social sustainability. This issue presents a foray into advancing debates around such practices.

Taking a lead into the relatively uncharted territory of the impacts the current financial crisis might have on sustainable city building, Evans, Jones and Krueger deliver a far reaching, internationally positioned exploration of the varied associations between sustainability policies, practices and urban regeneration projects. Their question, "can the credit crunch save our cities?" assertively repositions the potentiality of a retracted development market to open up the political space for the actualisation of urban sustainability agendas, programmes and projects which do not eclipse the social. Whether by default or design, a more sustainable future for cities is conceivable within a financial climate where the delivery of "diverse", "mixed", "green" urban projects dangerously reliant upon expedient and endowed private development activity is constrained. Evans, Jones and Krueger suggest that cities can and should take this opportunity to break away from the demonstratively tarnished status quo and exploit their own social capital to (re-)emphasise the organicism required for successful and sustainable regeneration and revitalisation. The normative changes in perspective, proposed by Evans, Jones and Krueger, underscore the possibility of re-orienting public policy agendas away from private sector-led urban development, "mega-projects", and the complex scalar arrangements of "PPPs" towards new forms of governance and community-based interventions in cities. Crucial to this challenge is a discursive reframing of what constitutes sustainable "development" and who counts as "developers".

\section{References}

Adair, A., Berry, J., and McGreal, S., 2003. Financing property's contribution to regeneration. Urban Studies, 40 (5), 1065-1080.

Boddy, M., 2007. Designer neighbourhoods: new-build residential development in non-metropolitan UK cities - the case of Bristol. Environment and Planning A, 39 (1), 86-105.

Bromley, R., Tallon, A., and Thomas, C., 2005. City centre regeneration through residential development: contributing to sustainability. Urban Studies, 42 (13), 2407-2429.

Bunce, S. and Desfor, G., 2007. Introduction to: "political ecologies of urban waterfront transformations". Cities, 24 (4), 251-258.

Bunce, S. and Young, D., 2004. Image-making by the water: global city dreams and the ecology of exclusion. In: INURA, ed. The contested metropolis: six cities at the beginning of the $21^{\text {st }}$ century. Basel, Switzerland: Birkhauser, 214-219.

Cowen, D. and Bunce, S., 2006. Competitive cities and secure nations: conflict and convergence in urban waterfront agendas after 9/11. International Journal of Urban and Regional Research, $30(2), 427-439$.

Davidson, M. and Lees, L., 2005. New-build gentrification and London's riverside renaissance. Environment and Planning A, 37 (7), 1165-1190.

Desfor, G. and Jorgensen, J., 2004. Flexible urban governance: the case of Copenhagen's recent waterfront development. European Planning Studies, 12 (4), 479-495.

Desfor, G. and Keil, R., 2004. Nature and the city: making environmental policy in Toronto and Los Angeles. Tuscon: University of Arizona Press.

Gibbs, D. and Krueger, R., 2007. Containing the contradictions of rapid development? New economy spaces and sustainable urban development. In: R. Krueger and D. Gibbs, eds. The sustainable development paradox: urban political economy in the United States and Europe. New York: Guildford Press, 95-122. 
Guy, S. and Farmer, G., 2001. Re-interpreting sustainable architecture: the place of technology. Journal of Architectural Education, 54 (3), 140-148.

Guy, S. and Shove, E., 2000. A sociology of energy buildings and the environment: constructing knowledge, designing practice. London: Routledge.

Hackworth, J., 2002. Post-recession gentrification in New York city. Urban Affairs Review, 37 (6), 815-843.

Hackworth, J. and Smith, N., 2001. The changing state of gentrification. Tijdschrift voor Economische en Sociale Geografie, 92 (4), 464-477.

Keil, R., 2007. Sustaining modernity, modernizing nature: the environmental crisis and the survival of capitalism. In: R. Krueger and D. Gibbs, eds. The sustainable development paradox: urban political economy in the United States and Europe. New York: Guildford Press, 41-65.

Krueger, R. and Agyeman, J., 2005. Sustainability schizophrenia or "actually existing sustainabilities"? Toward a broader understanding of the politics and promise of urban sustainability in the US. Geoforum, 34 (4), 410-417.

Lees, L., 2003. Visions of "urban renaissance": the urban task force report and the urban white paper. In: R. Imrie and M. Raco, eds. Urban renaissance? New labour, community and urban policy. Bristol, UK: Policy Press, 61-82.

Littig, B. and Greissler, E., 2005. Social sustainability: a catchword between political pragmatism and social theory. International Journal for Sustainable Development, $8(1 / 2), 65-79$.

Moore, S.A. and Engstrom, N., 2005. The social construction of "green building" codes: competing models by industry, government and NGOs. In: S. Guy and S.A. Moore, eds. Sustainable architectures: cultures and natures in Europe and North America. New York: Spon Press, 51-70.

Moore, S. and Rydin, Y., 2008. Promoting sustainable construction: European and British networks at the knowledge-policy interface. Journal of Environmental Policy and Planning, 10 (3), 233-254.

Raco, M., 2005. Sustainable development, rolled-out neo-liberalism, and sustainable communities. Antipode, 37 (2), 324-347.

Raco, M., 2007. Spatial policy, sustainability, and state restructuring: a reassessment of sustainable community building in England. In: R. Krueger and D. Gibbs, eds. The sustainable development paradox: urban political economy in the United States and Europe. New York: Guildford Press, 214-237.

Schubert, D., 2001. Ever changing waterfronts: Stadt-und hafenentwicklung und derumbau von uferzonen in Singapore. RaumPlanung, 94, 39-44.

Steinacker, A., 2003. Infill development and affordable housing: patterns from 1996-2000. Urban Affairs Review, 38 (4), 492-509.

Susan Moore

Bartlett School of Planning, University College London

Susannah Bunce

Department of Social Sciences, University of Toronto Scarborough 